\title{
Opinie
}

\section{Een zonderling in het maatschappelijk verkeer}

\author{
De betekenis van een concept-jaarrekening
}

\section{Prof J.H. Blokdijk}

De ondertitel van dit artikel is dezelfde als de titel van 'Audit Alert' 1993/3, een circulaire van het NIVRA aan de leden. Voor dat document is de titel misleidend: er wordt geen analyse van de betekenis van een concept-jaarrekening gegeven. Wel wordt een nogal wereldvreemde aanbeveling aan de leden gedaan, waarbij wordt verwezen naar een uitspraak van de Raad van Tucht d.d. 30 mei 1990, die op 28 februari 1991 is bevestigd door de Raad van Beroep. Na enig zoeken blijkt dit de uitspraak 1992/8 te zijn (zie De Accountant van mei 1992 en de bundel 'Jurisprudentie Tuchtrechtspraak' van het NIvRA).

Deze uitspraak heeft, met vertraging, nogal vreemde gevolgen. Wat is het geval?

\section{De voorgeschiedenis}

De in vorengenoemde tuchtzaak aangeklaagde accountant, zoals gebruikelijk en ook hierna aangeduid als 'betrokkene', heeft op verzoek van zijn cliënt aan een potentiële financier een concept-balans en een concept-resultatenrekening toegezonden. Op beide stukken was de aanduiding 'Concept' opgenomen. In het begeleidend schrijven heeft betrokkene volgens de uitspraak ter zake niet méér vermeld dan: 'De toezending ondervond helaas enige vertraging omdat ....... nog een correctie moest worden toegepast ...... In de rubricering van de cijfers in de resultatenrekening
19.. kan dit nog een onderlinge verschuiving ten gevolge hebben, het eindresultaat wijzigt daardoor niet meer.

Later heeft betrokkene bij deze stukken een goedkeurende verklaring gegeven. Nog later moet hij melden dat het resultaat over bedoeld boekjaar ca. $f 1.000 .000$ te hoog is voorgesteld, hetgeen kennelijk in dit geval van materieel belang was. Er is nog meer gebeurd, maar dat is hier niet ter zake.

De - inmiddels niet meer potentiële - financier dient vervolgens tegen betrokkene een klacht in, waarin de klager onder meer stelt dat betrokkene ten onrechte de indruk heeft gewekt dat eerdergenoemde concept-balans en concept-resultatenrekening gecontroleerd waren; ook stelt klager dat de later gegeven goedkeurende verklaring bij bedoelde jaarrekening ten onrechte is gegeven. Tegen deze laatste klacht heeft betrokkene kennelijk geen steekhoudend verweer gehad; deze klacht is dan ook gegrond verklaard. Tegen de eerstgenoemde klacht verweert betrokkene zich door te stellen dat hij alle stukken van de aanduiding 'Concept' had voorzien en voorts mondelinge voorbehouden heeft gemaakt.

Nu kan uit de vorengeciteerde tekst van het begeleidend schrijven naar mijn mening ge-

Prof. J.H. Blokdijk, registeraccountant, is directeur van J.H. Blokdijk Advies B.V. en adviseur van ondernemingen en accountants. Hoogleraar toegepaste Accountantscontrole aan de Vrije Universiteit Amsterdam. Heeft vele vaktechnische functies bij het NIvRA vervuld. Lid van bestuur van de Stichting Toezicht Effectenverkeer. 


\section{MAB}

makkelijk worden afgeleid dat aan de controle van de jaarrekening nog nauwelijks iets ontbrak. Welke de mondelinge voorbehouden waren. wanneer zij zijn gemaakt en of zij later nog tot wijzigingen in de jaarrekening hebben geleid, is uit de tekst van de uitspraak niet op te maken. Het is niet onwaarschijnlijk dat de klager door de begeleidende brief is misleid. althans tijdelijk

Met deze inhoudelijke overwegingen houdt de Raad van Tucht zich echter niet bezig. De Raad hanteert de strikt schriftgeleerde aanpak: betrokkene heeft niet één van de toenmalige in artikel 6 Gedrags- en Beroepsregels Registeraccountants (GBR) voorgeschreven bewoordingen gebruikt; daarom is de klacht gegrond verklaard. Enige weken na de uitspraak is betrokkene overleden. De erven, bijgestaan door een vaktechnisch adviseur van het kantoor waarvan betrokkene deel heeft uitgemaakt, tekenen beroep aan, kennelijk alleen tegen de uitspraak over de aanduiding 'Concept'; zij stellen dat een concept-verantwoording geen verantwoording is, waardoor artikel 6 GBR dus niet van toepassing is

De Raad van Beroep komt niet aan de bespreking van deze grief toe, omdat de wet de erven niet toestaat om in beroep te gaan, en (merkwaardigerwijze) omdat de Raad onvoldoende is gebleken dat de betrokkene in beroep had willen gaan. De erven worden niet ontvankelijk verklaard.

$\mathrm{Nu}$ lijkt het zeer waarschijnlijk dat het beroep is ingesteld in het belang van het accountantsberoep; immers, géen beroep is ingesteld tegen de veel ernstiger uitspraak dat de goedkeurende verklaring ten onrechte is gegeven. Het beroep is kennelijk geïnspireerd door het accountantskantoor waartoe de betrokkene heeft behoord. Voor de goede orde: ik ken noch de naam van het betrokken kantoor, noch die van de vaktechnisch adviseur.

\section{De aanbeveling}

Zeer opvallend is, dat het Bestuur van het $\mathrm{NI}$ VRA geen gebruik heeft gemaakt van het wet- telijk recht beroep aan te tekenen (art. 52 lid 3 van de toenmalige Wet op de Registeraccountants). Ongeveer drie jaar na de uitspraak zendt het NIvRA een 'Audit Alert' (sic!) uit, een circulaire waarin de consequenties van de uitspraak van de Raad van Tucht worden getrokken. Daarin wordt eerst uit de uitspraak van de Raad van Tucht de passage geciteerd waarin deze met een beroep op artikel 6 GBR de klacht gegrond verklaart. Vervolgens wordt de volledige tekst van artikel 6 GBR weergegeven. Dan wordt aanbevolen op (onderdelen van) concept-jaarrekeningen de volgende tekst aan te brengen: 'geen accountantscontrole toegepast; zie brief d.d. ....; in deze begeleidende brief ware de volgende zin op te nemen: 'Aangezien de accountantscontrole niet is voltooid en derhalve nog geen accountantsverklaring kan worden verstrekt, vermelden wij. op grond van de geldende Gedragsen Beroepsregelen, dat op deze concept-jaarrekening geen accountantscontrole is toegepast.' Vermeld wordt nog dat deze aanbeveling ook geldt voor andere conceptverantwoordingen dan jaarrekeningen.

\section{De consequenties}

In het midden- en kleinbedrijf komt het zeer vaak voor dat de accountant die is belast met de controle van de jaarrekening, het concept redigeert, ook al heeft hij niet de opdracht tot samenstelling van de jaarrekening; bij dergelijke ondernemingen ontbreekt vaak de daartoe noodzakelijke kennis van het jaarrekeningrecht.

Tegen de tijd dat de controle-opdracht is voltooid, maakt de accountant gewoonlijk met de leiding van deze ondernemingen een afspraak voor een bespreking waarin de jaarrekening in wettelijke zin wordt 'opgemaakt'; het doel van het gesprek is dat de ondernemingsleiding zich aan het einde van het gesprek akkoord verklaart met het voorgelegde, al dan niet tijdens de bespreking gewijzigde concept. Om dat gesprek goed voor te bereiden pleegt de accountant de concept-jaarrekening min- 


\section{MAB}

stens enkele dagen vór het gesprek aan de ondernemingsleiding toe te zenden.

De in dat gesprek door de leiding 'opgemaakte' jaarrekening dient dan de datum van de bespreking te dragen. De accountant vraagt dan per dezelfde datum een bevestiging bij de jaarrekening (Richtlijnen voor de Accountantscontrole 4.10.1, paragraaf 5.3). Vervolgens belet de accountant niets meer de accountantsverklaring af te geven, bij voorkeur met dezelfde datum als die van de jaarrekening (Richtlijnen voor de Accountantscontrole 3.05, paragraaf 2.4).

Maar wat gebeurt er als de accountant vorenstaande aanbeveling volgt? Hij zal bij vorenbedoelde slotbespreking door een verbijsterde ondernemingsleiding geconfronteerd worden met zijn eigen brief, waarin hij heeft vermeld dat geen accountantscontrole is toegepast. De accountant had toch de opdracht tot accountantscontrole aanvaard? Weigert hij deze uit te voeren? En wat hebben zijn medewerkers en assistenten dan wekenlang bij de onderneming zitten uitvoeren? Als dat werkzaamheden waren waartoe de ondernemingsleiding geen opdracht heeft gegeven, dan zullen die ook niet worden gehonoreerd! En wanneer is de accountantscontrole dan eindelijk klaar? De accountant die dit artikel nog niet heeft gelezen, schrikt hevig en tracht de gemoederen te sussen door als antwoord op de laatste vraag mede te delen dat hij de goedkeurende verklaring kan geven als men het eens wordt over de concept-jaarrekening en de ondernemingsleiding de bevestiging bij de jaarrekening geeft. Dit laatste is echter olie op het vuur. De directie stelt nu: 'Accountant, u past geen accountantscontrole toe, hoewel u daartoe de opdracht had, maar $u$ geeft een verklaring als u van ons een bevestiging heeft dat wij ons van geen kwaad in de jaarrekening bewust zijn!' De jarenlange moeite om de cliënt van de zin en betekenis van de bevestiging van de jaarrekening te overtuigen, is met één ongelukkige uitlating ongedaan gemaakt: direc teuren van kleine en middelgrote ondernemingen zijn de bevestiging bij de jaarrekening altijd blijven wantrouwen, ook al hebben velen hem de laatste jaren wel getekend, zij het eerder uit respect voor hun accountant dan uit overtuiging

De hevig geschrokken accountant haast zich uit te leggen dat het werk van zijn medewerkers en assistenten wel degelijk in het kader van de accountantscontrole van de jaarrekening is verricht, maar dat pas gezegd kan worden dat accountantscontrole is toegepast als die controle is voltooid. Uiteindelijk verwijst hij - conform de aanbeveling in 'Audit Alert 1993/3 voor de tekst van het begeleidende schrijven - naar de Gedrags- en Beroepsregels. Dat maakt de zaak ook niet beter. Uitgedaagd om de ratio van artikel 6 GBR uit te leggen, moet de accountant eerst stellen dat de concept-jaarrekening een 'verantwoording is. Dat is geheel niet naar de zin van de ondernemingsleiding: de directie stelt daartegenover dat de door de accountant geredigeerde concept-jaarrekening pas een verantwoording is als zij, de directie. deze als haar verantwoording aanvaardt! Niet de accountant, maar de directie legt verantwoording af, en zij doet dit door de jaarrekening te dateren, te ondertekenen en aan de tot oordelen bevoegde instanties voor te leggen.

De accountant in het zojuist beschreven tafereeltje bevindt zich dus in een benarde positie, waar wij hem verder transpirerend zullen achterlaten. Toch handelde hij strikt volgens de gezaghebbende geschriften. Die dwongen hem te zeggen dat hij iets niet gedaan had waaraan hij heel veel werk had verricht; dat werk kon nog niet worden afgerond omdat de accountantsverklaring niet gegeven kon worden. en wel doordat het stuk waarbij deze gegeven zou moeten worden er nog niet was! De gezaghebbende geschriften dwingen de accountant in een rol die in het normale maatschappelijke verkeer als zonderling zal worden ervaren.

\section{Wat is verkeerd gegaan?}

Uit het vorenstaande valt niet moeilijk af te leiden waardoor de schoen is gaan wringen. De 


\section{MAB}

erven van betrokkene in tuchtzaak 1992/8 hadden het bij het rechte eind toen zij beroep instelden op grond van de stelling dat een document dat de aanduiding: 'Concept' draagt het karakter van een ontwerp heeft, en dat een ontwerp-verantwoording (nog) geen verantwoording is. Raadpleging van woordenboeken uit de periode waarin het geval zich afspeelde (Van Dale, 1984, en de Grote Koenen, 1986), laten geen ruimte voor een andere interpretatie van het woord 'concept' dan 'voorlopige formulering', 'ruwe opzet' en 'ontwerp'. Voorts is duidelijk dat het woord 'ontwerp' in combinatie met de omschrijving van een document een ontkrachtend karakter heeft: men hoeft zich (nog) niet te houden aan een ontwerp van een wet of van een verordening. Ontwerpen worden volgens Van Dale (1984) met name gemaakt om deze 'aan anderen ter overweging aan te bieden'. In het dagelijkse spraakgebruik zal de aanduiding 'Concept' in het algemeen duidelijk maken dat de inhoud van het aldus aangeduide document zeker nog kan veranderen alvorens deze definitief wordt vastgesteld; in het normale maatschappelijke verkeer zal 'concept-jaarrekening' dan ook in deze zin worden begrepen.

En als accountants dat nu óók maar deden, of mochten doen, dan was er niets aan de hand: het gehele vorengeschetste tafereeltje kan worden voorkomen als de accountant niet gedwongen is op of over concept-verantwoordingen mede te delen dat geen accountantscontrole is toegepast. Onder de huidige uitspraken dient de accountant zich te gedragen als een zonderling in het maatschappelijk verkeer.

Het is duidelijk dat de Raad van Tucht met zijn onnadenkende schriftgeleerde benadering de kiem voor het kwaad heeft gelegd. Het Bestuur van het NIvRA was niet alert genoeg om in beroep te gaan, maar miste later ook de wijsheid om de ongelukkige uitspraak van de Raad van Tucht in de vergetelheid te doen wegzinken. Het achterwege blijven van 'Audit Alert' 1993/3 zou al winst geweest zijn; het daarin aanbevolen beroep op de regelgeving is, bij gebrek aan argumenten, natuurlijk een zwaktebod. Zuivere schriftgeleerdheid pleegt te leiden tot zinledige rituelen. Inmiddels nadert het jaarrekeningseizoen 1993 voor het middenen kleinbedrijf, voorzover dat wat later ligt dan voor het grootbedrijf. Als accountants zich keurig aan de regels houden, zullen velen de geschetste zonderlinge rol moeten vertolken; meestal ongewild, vermoedelijk.

\section{Wat nu?}

Het Bestuur van het NIvRA zal de moed moeten opbrengen luid en duidelijk te stellen dat een ontwerp van een verantwoording géén verantwoording is. Mocht de Raad van Tucht te eniger tijd wéér anders oordelen, dan zal het Bestuur in beroep moeten gaan.

Maar ook individuele accountants moeten zorgvuldiger zijn dan de betrokkene in tuchtzaak 1992/8. Voorzover uit de tekst van de uitspraak van de Raad van Tucht was op te maken, wekte het begeleidend schrijven waarin de concepten werden aangeboden althans bij mij de indruk dat er aan de jaarrekeningcontrole nauwelijks meer iets ontbrak. Als deze indruk niet juist is, is de aanduiding 'Concept' onvoldoende om deze te bestrijden; een concept wordt immers aan een ander toegezonden omdat het de geadresseerde in zekere mate ten nutte zou kunnen zijn. Als dat nut beperkt is, moet dat de ontvanger van het concept-document duidelijk worden gemaakt. Daartoe behoort het begeleidend schrijven te dienen.

Bij toezending van een concept-jaarrekening is het zinvol in het begeleidend schrijven aan te geven over welke posten de accountant nog van gedachten wil wisselen, en op welke punten de controle nog niet is voltooid. Deze aangelegenheden behoeven niet uitgebreid te worden omschreven, maar kunnen kort worden aangeduid; de ontvanger weet dan op welke punten hij nog verrassingen kan verwachten en welke cijfers hij voorshands met voorzichtigheid moet hanteren.

Voorts wordt in 'Audit Alert' 1993/3 de zinvolle aanbeveling gedaan in concept-verantwoordingen geen concept van de accountantsver- 
klaring op te nemen. Mocht de accountant overwegen een andere dan een standaard goedkeurende verklaring te geven, dan kan hij de voorgenomen afwijkingen van de standaardtekst beter in de begeleidende brief presenteren.

In de concept-fase is het begeleidend schrijven dus van groot belang om de positie van de accountant te markeren; het is dan ook zinvol de concept-verantwoording te voorzien van de aanduiding: 'Bijlage bij brief d.d. ...' Anderzijds moet de aanduiding 'Concept' op de ontwerp-verantwoording voldoende zijn om degenen die daar kennis van nemen te waarschuwen.

\section{De moraal}

Het beroep moet maatregelen nemen om te voorkomen dat accountants onder een 'concept' iets anders moeten verstaan dan elke andere deelnemer aan het maatschappelijk verkeer. Degene die voor zichzelf eigen verkeersregels hanteert, zal zich in het verkeer zonderling gedragen. Bovendien kon hij wel eens boetes (lees: claims) krijgen. 